\title{
13. An Empirical Study of China's High-Tech Industry Innovation Capability in Transition
}

\section{Zhiyun Zhao and Chaofeng Yang}

\section{Introduction}

Since the reform and opening up, the growth mode of China's economy has essentially featured a heavy reliance on investment and exports and intense input of low-cost resources and factors. Such a mode was reasonable to some extent when China lagged behind in economic development and its economic aggregate accounted for a relatively small proportion of the world economy. With China's continuous economic growth, however, the costs of this growth mode have become increasingly large, including resource depletion, environmental damage, a gradually widening wealth gap, significantly increased social conflicts and more frequent international trade friction. The international financial crisis and the severe recession that it triggered spelt an end to the rapid economic growth experienced since the 1980s, and especially since the turn of the new century, which caused a profound adjustment of the global economy. Consequently the external environment for China's development has changed deeply and extensively. Urgent demands are thus generated for China to transform its economy as soon as possible from the traditional economic growth mode based on resources, capital and labour to the new mode based primarily on innovation.

The high-tech industry, with characteristics of high growth, large driving forces and high value added, is a strategically leading industry in the national economy, playing an important role in industrial restructuring and transformation of the economic development pattern. In 2010, the total output value of China's high-tech industry reached RMB7.47 trillion, accounting for 10.56 per cent of the total output value of the large and medium-sized enterprises in that year. China has become the world's major manufacturing base for high-tech products, with an important role in the international hightech production chain. During the development process, however, there have been several problems in China's high-tech industry, including weak innovation capacity, low technology intensity and poor economic efficiency. A top agenda 
item for China's government, high-tech industry and academia is to improve the innovation capability of China's high-tech industry and make it play a greater role in China's ongoing economic transformation.

In recent years, some scholars have carried out empirical research on innovation performance in China from the regional and industrial points of view. The major studies from a regional perspective of innovation efficiency in China are summarised as follows. Shi and Zhao (2009) calculate the regional innovation efficiency in China and analyse its spatial discrepancy using the stochastic frontier approach. Li (2007) conducted an empirical analysis of the efficiency factors influencing the regional innovation capability differences in China, taking the number of invention patent applications granted as indicators of innovation output. Guo et al. (2007) analysed the ability of technology innovation and its influencing factors for the six provinces of central China by establishing a knowledge production function model with fixed effects and variable intercept. Yang (2008) studied the technological innovation capacity of large and medium-sized enterprises in different regions and conducted a comprehensive evaluation using the factor analysis method. The major literature on Chinese innovation efficiency from an industrial perspective is summarised as follows. Zhang and Feng (2007), through their panel data analysis of 28 sectors in China's high-tech industry, discussed the relationship between market structure, research and development (R\&D) investment and economic performance under different industrial characteristics. Zhi (2009) used the stochastic frontier method to analyse the technological innovation performance of China's electronic information industry. Han (2010) also applied the stochastic frontier method to conduct an empirical analysis of the innovation efficiency of China's high-tech industry. These studies have contributed a lot to this research field and provide a number of policy ideas to promote China's innovation capacity; however, there are also some shortcomings in previous studies, which can be viewed from the following three aspects. First, the majority of scholars selected sales revenues of new products and the number of patent applications as the output indicators of innovation. Though it is generally believed that the number of patents - information for which is relatively easy to obtain and use in statistical analyses - is a good indicator of innovation output, there are still some limitations. On the one hand, not all innovation will be registered as patents. On the other hand, the tendency to apply for patents varies with enterprises' size. Large enterprises often rely on a monopoly of market and technology to protect innovation while small companies are more willing to apply for patents in order to protect their innovation from infringements by other companies with more resources (Comanor and Scherer 1969). These are issues that should be addressed in future research. Second, when choosing indicators of innovation, most scholars do not take the knowledge stock into account. The generation of new knowledge depends not only on investment in $\mathrm{R} \& \mathrm{D}$ and personnel, 
but also on the existing knowledge stock. Third, when choosing the factors affecting innovation efficiency, most scholars consider market structure and government support for innovation activities. These factors are very important when examining the innovation efficiency of different countries, but they are not necessarily differentiating across industries in the one country. For China, as an economy in transition, factors that affect innovation efficiency should be determined by taking into consideration the characteristics of regional or industrial development during the transition period.

This chapter strives to achieve a breakthrough in the above aspects. An analytical model is established to evaluate the innovation capability of hightech industries in China, and the influencing factors of innovation capability are discussed. The chapter is organised as follows: the first section is the introduction; the second section briefly analyses the characteristics of China's high-tech industries during the transition period; the third section introduces the model and accounts for the variable selection; the fourth section details the empirical analysis; and the final section contains the conclusions and policy recommendations.

\section{Characteristics of China's High-Tech Industry During the Transition Period}

Since its entry into the World Trade Organisation (WTO), China has witnessed rapid growth in its high-tech industry and has leapt into the front ranks of the world in terms of scale through taking an active part in economic globalisation. But, unlike developed countries, China's economic system is in a transitional period. In such a special period, the development of China's high-tech industry is significantly distinct from that of developed countries.

\section{Significantly Increased R\&D Activities}

In recent years, investments in $\mathrm{R} \& \mathrm{D}$ activities and personnel for China's high-tech industry have increased dramatically. R\&D expenditures expanded rapidly from RMB36.25 billion in 2005 to RMB96.78 billion in 2010, increasing 170 per cent in six years. R\&D personnel rose from 173000 people (full-time equivalent) in 2005 to 399000 people in 2010 - an increase of 130 per cent in six years (Figure 13.1). 
Rebalancing and Sustaining Growth in China

Figure 13.1 R\&D Investments of China's High-Tech Industry, 2005-10

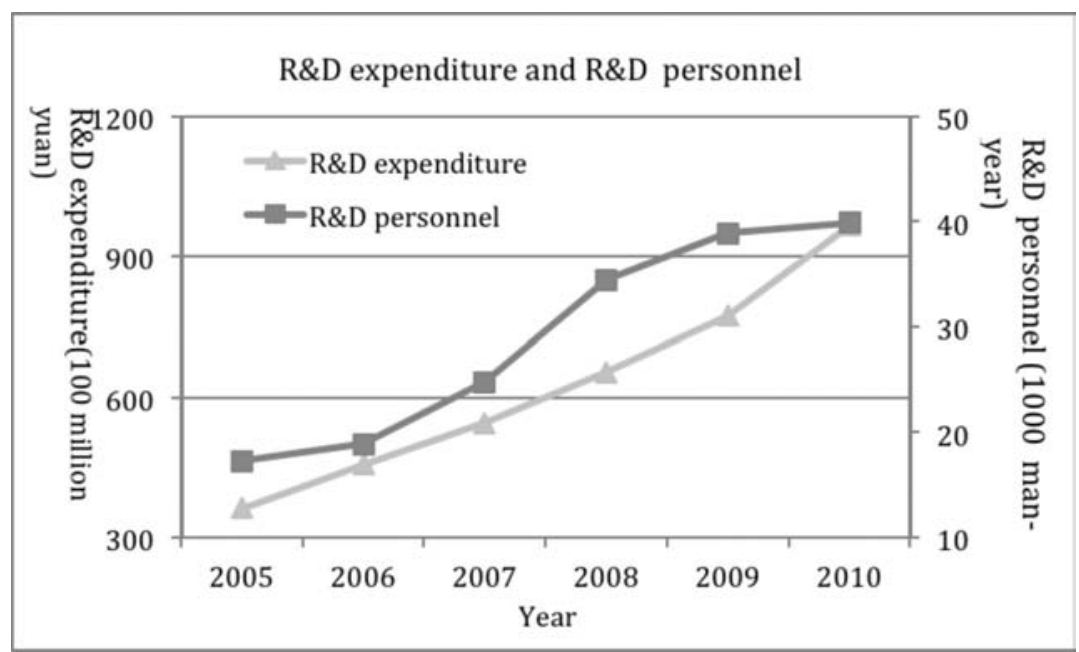

Source: Authors' own calculation using the data from China Statistical Yearbook on Science and Technology.

Driven by these investments, the R\&D output of the high-tech industry in China has grown rapidly. There were less than 10000 invention patent applications in China's high-tech industries in 2005, but there were 35000 applications in 2010, increasing at an average annual growth rate of 29.7 per cent. Such a growth rate is rare even in developed countries. At the same time, the number of invention patents in force owned by China's high-tech industries had soared to more than 50000 in 2010 (Figure 13.2).

Figure 13.2 Number of Invention Patents in China's High-Tech Industry, 2005-10

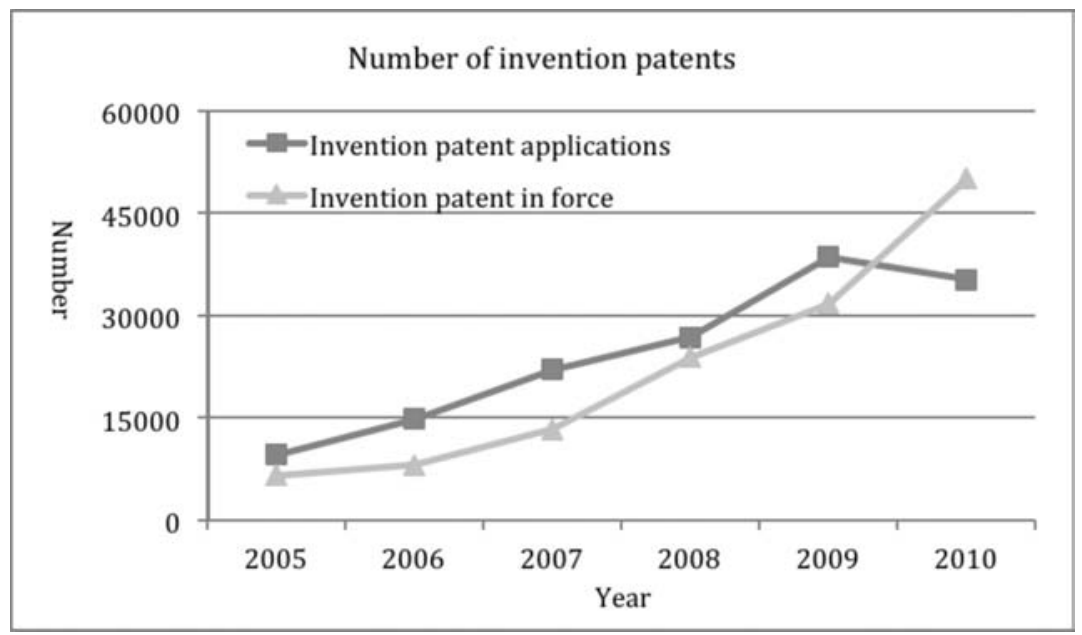

Source: Authors' own calculation using the data from China Statistical Yearbook on Science and Technology. 


\section{Low R\&D Intensity and Productivity}

Technology intensity is a basic international standard for high-tech industry. Only those industries with technology intensity significantly higher or several times higher than the average intensity of all manufacturing industries can be defined as high-tech industries. R\&D expenditure intensity is an important indicator of technology intensity. In the United States, Germany, France, Britain and other developed countries, the R\&D intensity of the high-tech industries is three or four times higher than the average level of manufacturing industries. In contrast, the R\&D intensity of China's high-tech industry (1.3 per cent) was only about two times that of the manufacturing industry (0.62 per cent) in 2010 - far lower than the level of the abovementioned countries (Figure 13.3). This indicates that the technology intensity of China's high-tech industries is still low and the innovation capacity of enterprises is relatively poor.

Figure 13.3 R\&D Intensity of China's High-Tech Industry, 2006-10

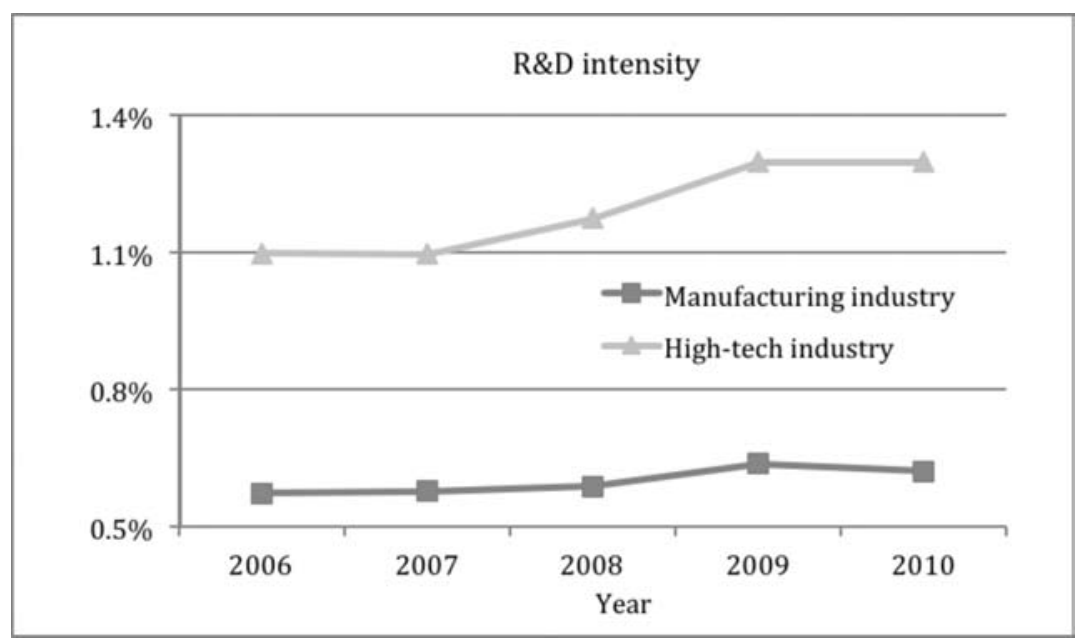

Source: Authors' own calculation using the data from China Statistical Yearbook on Science and Technology.

Paradoxically, 'low-tech' is a more appropriate description of China's 'hightech' enterprises. Although the products they produce are called 'high-tech products', they assemble such products rather than design and build them completely. The rapid expansion of China's high-tech industry in the past six years was based on scale expansion more than on industrial upgrading. The overall labour productivity of China's manufacturing industry was RMB726 400 per capita in 2010 - an increase of 100 per cent compared with that of 2005; meanwhile, the overall labour productivity in high-tech industry increased by only 32 per cent. The labour productivity of China's high-tech industry in 2010 
was even lower than the overall level of the manufacturing industry, reflecting the slow improvement of production efficiency in China's high-tech industry (Figure 13.4).

Figure 13.4 Labor Productivity of China's High-Tech Industry and Manufacturing Industry, 2005-10

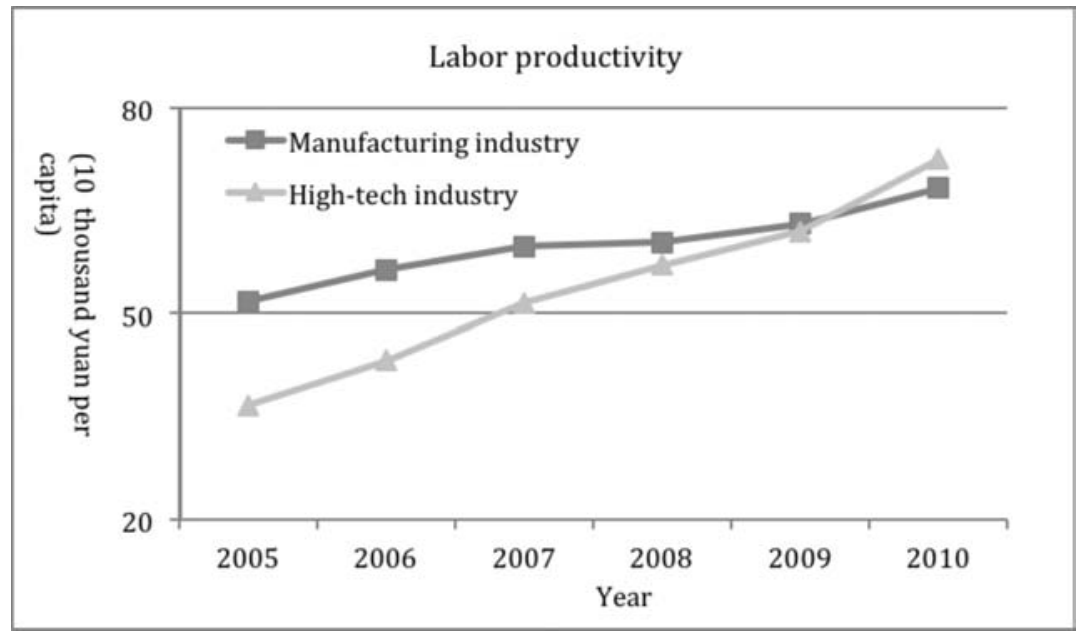

Source: Authors' own calculation using the data from China Statistical Yearbooks and China Statistical Yearbook on Science and Technology.

\section{Acquiring Technologies Mostly from Domestic Providers}

The external channels of technology acquisition for China's high-tech industry mainly include acquisition of foreign technologies and the purchase of domestic technologies. During the period 2005-10, China's high-tech industry experienced an increase and then a decrease in its expenditures for acquisition of foreign technologies, with the peak - RMB13 billion - in 2007. Since then, it has decreased continuously, to RMB6.88 billion in 2010 - almost half of that in 2007 and RMB1.6 billion less than in 2005 (Figure 13.5). At the same time, the funds for purchasing domestic technologies of high-tech industries in China increased steadily, from RMB950 million in 2005 to RMB2.13 billion in 2010. This indicates the gradual change in the technology sources of China's high-tech industries from foreign channels towards domestic providers. 
Figure 13.5 Expenditure for Acquisition of Foreign Technology and Purchase of Domestic Technology of China's High-Tech Industry, 2005-10

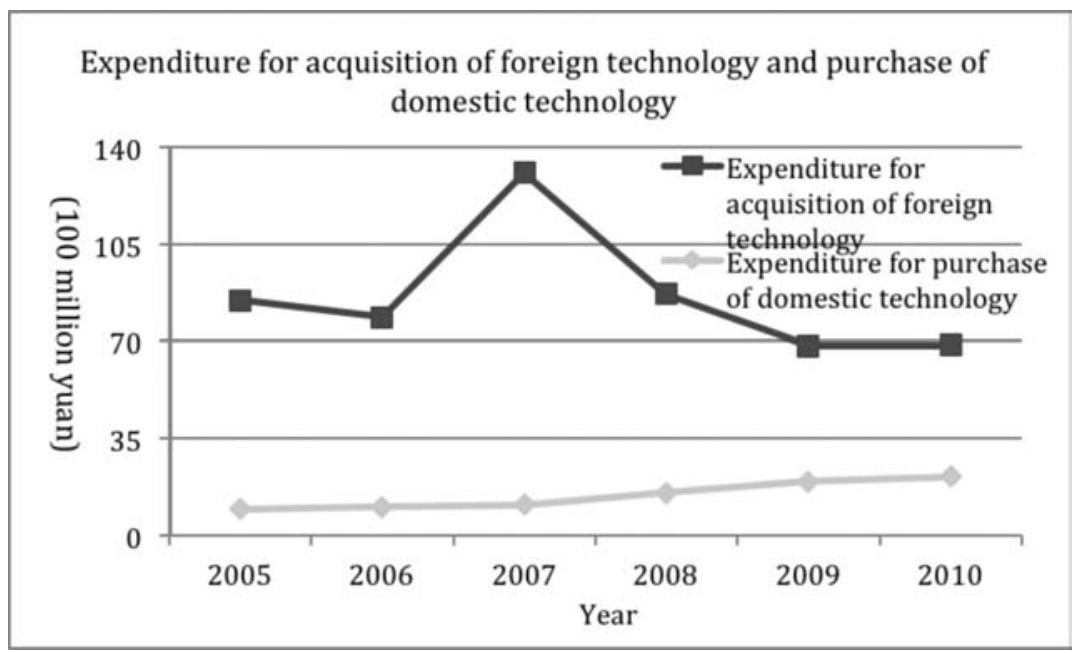

Source: Authors' own calculation using the data from China Statistical Yearbooks and China Statistical Yearbook on Science and Technology.

\section{Research Methods and Data}

As innovation is a process of knowledge production and commercialisation, we can explore the industry's innovation capability through the knowledge production function. The knowledge production function was initially proposed by Griliches (1979) when he estimated the contribution of R\&D to economic growth using the production function. Improved by Jaffe (1989), the GrilichesJaffe knowledge production function model was developed. The knowledge production function connects the inputs and outputs of innovation, thus, we can get a better understanding of the driving forces, nature and influencing factors of knowledge production through the study of it, and furthermore promote knowledge production and innovation. A large body of empirical research has found that a knowledge production function does exist in the real world and that it is a good statistical model for the study of knowledge and innovation. It has been proven by most empirical studies at the national or industry level (Anselin et al. 1997; Blind and Grupp 1999; Bode 2004). The Griliches-Jaffe knowledge production function in Cobb-Douglas form can be described as follows (Equation 13.1).

Equation 13.1

$$
K_{i}=R D_{i}^{\alpha} Z_{i}^{\delta} e_{i}
$$


In Equation 13.1, $K$ denotes the innovation output; $R D$ denotes $R \& D$ investment; $Z$ is the series of factors that affects innovation output (such as knowledge stock); $e$ is random disturbances; and $i$ are decision-making units in high-tech industries.

Given the shortcomings we have identified regarding the use of the number of patents to measure innovation output, we use the number of new product development projects and sales revenue of new products to measure the innovation output in this study. According to the definition in the China Statistical Yearbook on Science and Technology (NBS 2009), the new product time series captures 'new products developed and produced by adopting new technological principles and new design concepts, or products with performance obviously enhanced or functions expanded through significant improvement in structure, material or techniques of the original products'. The new products include both those that have applied for patents and those that have not yet applied. Using the number of new product development projects can overcome the estimation bias caused by the differences of tendency to apply for patents across industries. In addition, in order to make up for the weakness of the number of new product development projects in measuring the direct contribution of innovation to economic growth, we also use the sales revenue of new products to measure the innovation output. It should be noted that it is also inappropriate to measure the innovation output with the sales revenue of new products only, because the industry's innovation capability is not necessarily strong when the sales revenue of new products is high considering the market size of different industries. Thus, it is better to use both indicators.

Compared with the measurement of innovative output, the measurement of innovation is relatively easy. Considering the characteristics of knowledge production, in addition to the $\mathrm{R} \& \mathrm{D}$ expenditure and $\mathrm{R} \& \mathrm{D}$ personnel, we regard the knowledge stock as an important input factor of knowledge production, for the knowledge stock could reflect the knowledge production status quo and development potential of technological innovation of an industry or a region. It is also a key measure of industrial or regional innovation capability. There have been no uniform standards for the estimation of knowledge stock. Following the approach used by Acs et al. (2002), the number of effective invention patents is used to measure the knowledge stock here.

For the factors affecting innovation output, combined with the characteristics of the transitional economy, we consider three factors: the expenditure for acquisition of foreign technology, the purchase of domestic technology and enterprise size. In developed countries, innovation is mainly performed through $\mathrm{R} \& \mathrm{D}$ activities; but in an economy in transition, innovation is based more on technological learning, mainly through the absorption of external technologies instead of independent R\&D efforts (Gil et al. 2003). In addition, with regard to 
the impact of enterprise size on innovation output, it is commonly agreed that such an impact exists, though views differ on whether the innovation efficiency is higher in small enterprises or in large enterprises. In this chapter, the average output value per enterprise in the industry is adopted to measure the size of the enterprise in the high-tech industry.

A defect in using traditional regression analysis to estimate a knowledge function is the assumption that production is carried out on the production possibility frontier. But in fact, most producers often deviate from the optimal production plan, resulting in inefficiency to some extent. There are usually two types of methods to identify inefficient items: parametric and non-parametric methods. Data envelope analysis is the main non-parametric method. It establishes the production frontier through linear programming and uses the distance function to calculate the efficiency of the production unit. The advantage of this method is that there is no need to assume a particular form of production function or make an assumption of the distribution of inefficiency in the sample(s). Its flaw is its assumption that there are no random errors affecting the output. Stochastic frontier analysis is the main parametric method. It is based on the idea of dividing the deviation of the actual production unit from the frontier into random error and inefficiency, estimating the frontier production function using the metric method. Compared with data envelope analysis, stochastic frontier analysis has a more solid theoretical foundation and can separate the potential impact caused by random errors and provide a variety of statistical tests to judge the quality of model fit. So, we choose the stochastic frontier model for our estimation.

The stochastic frontier model was first put forward by Aigner et al. (1977) and Meeusen and van den Broeck (1977), then expanded and developed by Jondrow, Battese and Coelli and other researchers with the flexibility and applicability improved. According to the definition of the stochastic frontier production function by Battese and Coelli (1995), we set up the stochastic frontier knowledge production function model as follows (Equations 13.2-5).

Equation 13.2

$y_{i t}=\alpha^{0} \cdot R D K_{i t}^{\alpha^{1}} \cdot R D L_{i t}^{\alpha^{2}} \cdot K S_{i t}^{\alpha^{3}} \cdot \exp \left(v_{i t}-u_{i t}\right)$

Equation 13.3

$v_{i t} \sim N\left(0, \sigma_{v}^{2}\right)$

Equation 13.4

$u_{i t} \sim T N\left(m_{i t}, \sigma_{u}^{2}\right)$ 
Equation 13.5

$$
m_{i t}=\delta_{0}+\delta_{1} T I F_{i t}+\delta_{2} T I D_{i t}+\delta_{3} E S_{i t}
$$

RDK denotes R\&D expenditure; RDL denotes R\&D personnel; KS is the knowledge stock measured by the number of invention patents in force; $v_{i t}$ is the random observation error normally distributed and independent of $\mathrm{u}_{\mathrm{it}}{ }^{\prime}$ the inefficient error, which is a random variable from a truncated normal distribution with its mean as $\mathrm{m}_{\mathrm{it}}$ and variance as $\sigma_{v}^{2} ; \mathrm{m}_{\mathrm{it}}$ is expressed as a linear combination of a set of influencing factors; TIF is the expenditure for acquisition of foreign technologies; TID is the expenditure for purchase of domestic technologies; and ES is the enterprise size.

Compared with more traditional estimation methods, the advantages of stochastic frontier analysis lie in its consideration of the inefficiency item. How then to determine the effectiveness of the stochastic frontier function? If there is no inefficient item in the model or the inefficient item is not obvious, it would be more appropriate to use the traditional method. According to Battese and Corra (1977), the coefficient of variation can be used to determine the effectiveness of the frontier function model. The coefficient of variation is defined as follows (Equation 13.6).

Equation 13.6

$$
\gamma=\frac{\sigma_{u}^{2}}{\sigma_{u}^{2}+\sigma_{v}^{2}}, 0 \leq \gamma \leq 1
$$

When $\mathrm{Y}$ is close to one, indicating that the inefficient item accounts for the main part of the deviation of the production units from the frontier, it is appropriate to use the frontier function model; if $\mathrm{Y}$ is close to zero, indicating that the random error is the main component, it is better to use traditional estimation methods.

After the effectiveness of the model is tested, the estimated value of innovation efficiency can be calculated by the following formula (Kumbhakar and Lovell 2000) (Equation 13.7).

\section{Equation 13.7}

$I E_{i t}=E\left\{\exp \left(-u_{i t}\right) \mid\left(v_{i t}-u_{i t}\right)\right\}$

The data in this chapter come from the China Statistical Yearbook and China Statistical Yearbook on Science and Technology. According to the related statistical indicators of the National Bureau of Statistics, China's high-tech industry is divided into five major categories (namely, medicine manufacturing industry, 
aircraft and spacecraft manufacturing industry, electronic and communication equipment manufacturing industry, computers and office equipment manufacturing industry, and medical equipment and meters manufacturing industry), which are further divided into 17 classes. Each class of industries is treated as a decision-making unit. The sample period is 2005-10. The descriptive statistics for all variables are shown in Table 13.1.

Table 13.1 Descriptive Statistics of Variables

\begin{tabular}{|c|c|c|c|c|}
\hline & Maximum & Minimum & Mean & $\begin{array}{l}\text { Standard } \\
\text { deviation }\end{array}$ \\
\hline $\begin{array}{l}\text { Sales revenue of new } \\
\text { products (RMB10 000) }\end{array}$ & 42748772.6 & 37857.00 & 6742440.14 & 8750481.42 \\
\hline $\begin{array}{l}\text { Number of new product } \\
\text { development projects } \\
(10 \text { 000) }\end{array}$ & 9316.00 & 57.00 & 2179.94 & 2162.41 \\
\hline $\begin{array}{l}\text { R\&D expenditure } \\
\text { (RMB10 000) }\end{array}$ & 3047068.40 & 14160.00 & 382918.57 & 491888.58 \\
\hline$R \& D$ personnel (man-years) & 98637.00 & 341.00 & 16845.96 & 19518.94 \\
\hline $\begin{array}{l}\text { Number of invention } \\
\text { patents in force }\end{array}$ & 23979.00 & 2.00 & 1428.87 & 3040.46 \\
\hline $\begin{array}{l}\text { Expenditure for acquisition } \\
\text { of foreign technologies } \\
\text { (RMB10 000) }\end{array}$ & 335532.00 & 0.00 & 50658.77 & 76498.78 \\
\hline $\begin{array}{l}\text { Expenditure for purchase } \\
\text { of domestic technologies } \\
\text { (RMB10 000) }\end{array}$ & 222193.00 & 0.00 & 10357.91 & 24574.96 \\
\hline $\begin{array}{l}\text { Enterprise size ( } 0.1 \text { billion/ } \\
\text { enterprise) }\end{array}$ & 64.48 & 0.44 & 4.06 & 9.72 \\
\hline
\end{tabular}

Source: Authors' own calculation based on data from China Statistical Yearbook on Science and Technology.

\section{Empirical Results and Analysis}

\section{Estimation Results}

The estimation software we used is FRONTIER4.1. In order to reduce the impact of outliers on the estimated results and make the estimated coefficient easier to explain (as a coefficient of elasticity), all variables were converted to natural logarithms. In addition, in terms of the input/output delay that must be dealt with in the model estimation, most researchers set it as long as one year when facing direct R\&D output (such as the number of patent applications), and two years when facing indirect R\&D output (such as the contribution of $\mathrm{R} \& \mathrm{D}$ investments to economic growth). According to the above tradition, the input/output delay is set to two years when the sales revenue of new products 
is used as an innovation output indicator, and one year when the number of new product development projects is used as an innovation output indicator. Table 13.2 shows the estimation results under different conditions.

Table 13.2 Estimation Results

\begin{tabular}{l|r|r|r|r|r|r}
\hline Variables & \multicolumn{3}{|c|}{$\begin{array}{c}\text { Number of new product } \\
\text { development projects }\end{array}$} & \multicolumn{2}{c}{ Sales revenue of new products } \\
\cline { 2 - 6 } & Coefficient & $\begin{array}{c}\text { Standard } \\
\text { deviation }\end{array}$ & T value & Coefficient & $\begin{array}{c}\text { Standard } \\
\text { deviation }\end{array}$ & T value \\
\hline Factors affecting the function frontier & & & \\
\hline Constant & 0.57993 & 0.92501 & 0.62694 & $5.04503^{*}$ & 2.43261 & 2.07392 \\
\hline RDK & $0.40839^{*}$ & 0.18123 & 2.25345 & $1.41651^{*}$ & 0.25939 & 5.46102 \\
\hline RDL & $0.20830^{*}$ & 0.20996 & 1.99205 & $0.71739^{*}$ & 0.22210 & 3.22998 \\
\hline KS & $0.11571^{*}$ & 0.06575 & 1.75985 & 0.02347 & 0.11030 & 0.21274 \\
\hline Factors affecting the efficiency & & & & \\
\hline Constant & 0.97835 & 0.62917 & 1.55498 & $4.28012^{*}$ & 1.49926 & 2.85482 \\
\hline TIF & -0.03579 & 0.03065 & -1.16755 & -0.14040 & 0.13325 & -1.05366 \\
\hline TID & $-0.12382^{*}$ & 0.03564 & -3.47410 & -0.21459 & 0.19943 & -1.07600 \\
\hline ES & $0.34534^{*}$ & 0.10922 & 3.16196 & $-0.78163^{*} *$ & 0.65169 & -1.29939 \\
\hline Model test and other settings & & & & \\
\hline $\begin{array}{l}\text { Coefficient } \\
\text { of variation }\end{array}$ & 0.82484 & 0.11044 & 7.46872 & 0.89179 & 0.08528 & 10.45677 \\
\hline Delay & & & & & & \\
\hline $\begin{array}{l}\text { Sample } \\
\text { size }\end{array}$ & & & & & & \\
\hline
\end{tabular}

* statistically significant at the 1 per cent level

** statistically significant at the 5 per cent level

*** statistically significant at the 10 per cent level

Source: Authors' own estimation.

It can be seen from the coefficient of variation estimated through the stochastic frontier model in the antepenultimate row of Table 13.2 that a considerable part of the variance can be attributed to the efficiency factor under both assumptions. It strongly supports our use of the stochastic frontier analysis model.

Known from Table 13.2, the number of new product development projects is significantly correlated with the R\&D expenditure and R\&D personnel, as well as the knowledge stock, while the sales revenue of new products is significantly correlated with the R\&D expenditure and R\&D personnel, but not with the knowledge stock. One possible reason for this difference is the lower quality of R\&D outputs in China's high-tech industry; many R\&D outputs can be used for further $R \& D$ activities and produce patents, but only a relatively small proportion of them can be successfully commercialised. In terms of the size of the 
coefficients, the estimation results show that, if the R\&D expenditure increases by 1 per cent, the number of new product development projects will increase by 0.41 per cent and sales revenue will increase by 1.42 per cent, assuming that other variables are constant; if the number of $R \& D$ personnel increases by 1 per cent, the number of new product development projects will increase by 0.21 per cent and sales revenue will increase by 0.72 per cent. The direct $\mathrm{R} \& \mathrm{D}$ output/input coefficient is large while the final output/input coefficient is small, which, to some extent, confirms the view previously mentioned that the rapid expansion of China's high-tech industries is more a scale expansion at low technical level without the quality of economic growth improving accordingly.

As to the factors affecting the innovation efficiency of China's high-tech industry, the expenditure for acquisition of foreign technologies is statistically significant neither with the number of new product development projects nor with sales revenue of new products, indicating that the acquisition of foreign technologies had no important influence on the innovation capability of China's high-tech industry during the sample period. One possible reason for this result is that, compared with other industries, developed countries impose more strict limits on high technology exports against developing countries due to intellectual property concerns so that China's high-tech industries might benefit from the introduction of foreign technologies in a very limited way.

When using the number of new product development projects as the measure of innovation output, the estimated coefficient of expenditure for the purchase of domestic technologies is negative and statistically significant. It indicates that the mean of inefficiency level $u_{i t}$ will decrease with the increase of expenditure for the purchase of domestic technologies and thereby the innovation efficiency will increase. This shows that the R\&D achievements of China's R\&D institutions other than high-tech enterprises play a significant role in promoting the R\&D activities in high-tech industry. When using the sales revenue of new products as a measure of innovation output, the estimated coefficient of expenditure for the purchase of domestic technologies is negative but statistically insignificant. It shows the introduction of domestic technologies by high-tech industry has no significant impact on its final innovation output. To some extent, this result suggests that high-tech enterprises in China focus more on the introduction of assembly lines than on the absorption and commercialisation of technology.

When using the number of new product development projects as the measure of innovation output, the estimated coefficient of enterprise size is positive and statistically significant. This means the enterprise size has a negative impact on the innovation output of China's high-tech industry. When using the sales revenue of new products as the measure of innovation output, the coefficient of enterprise size is negative and statistically significant, indicating that the enterprise size has a positive impact on the innovation output of China's high- 
tech industry. This apparently confusing result is not necessarily contradictory. It is a general problem that China's large-scale enterprises pay little attention to $\mathrm{R} \& \mathrm{D}$, but these enterprises can acquire more economic benefits (extract higher margins) from a small number of innovations through their market power.

\section{Comparison of Innovation Efficiency}

Using the model estimation results, we can calculate the estimated innovation efficiency of the 17 industries in each year (see Tables 13.3 and 13.4).

Table 13.3 Estimated Innovative Efficiency (with the number of new product development projects as the indicator of innovation output)

\begin{tabular}{|l|l|l|l|l|l|l}
\hline Industry & 2006 & 2007 & 2008 & 2009 & 2010 & Mean \\
\hline Chemical medicines & 0.732 & 0.661 & 0.807 & 0.791 & 0.622 & 0.723 \\
\hline $\begin{array}{l}\text { Finished traditional Chinese } \\
\text { medicines }\end{array}$ & 0.706 & 0.617 & 0.750 & 0.714 & 0.447 & 0.647 \\
\hline $\begin{array}{l}\text { Biological and biochemical } \\
\text { products }\end{array}$ & 0.426 & 0.475 & 0.702 & 0.664 & 0.274 & 0.508 \\
\hline Aeroplane making and repair & 0.575 & 0.642 & 0.497 & 0.463 & 0.447 & 0.525 \\
\hline Spacecraft & 0.222 & 0.391 & 0.172 & 0.077 & 0.046 & 0.181 \\
\hline Communications equipment & 0.210 & 0.223 & 0.386 & 0.442 & 0.199 & 0.292 \\
\hline Radar and its fittings & 0.592 & 0.541 & 0.503 & 0.398 & 0.484 & 0.504 \\
\hline $\begin{array}{l}\text { Broadcasting and television } \\
\text { equipment }\end{array}$ & 0.711 & 0.270 & 0.570 & 0.487 & 0.185 & 0.445 \\
\hline Electronic appliances & 0.534 & 0.707 & 0.746 & 0.706 & 0.392 & 0.617 \\
\hline Electronic components & 0.898 & 0.724 & 0.827 & 0.763 & 0.594 & 0.761 \\
\hline Domestic televisions and radios & 0.688 & 0.679 & 0.634 & 0.506 & 0.495 & 0.600 \\
\hline Other electronic equipment & 0.374 & 0.321 & 0.808 & 0.474 & 0.272 & 0.450 \\
\hline Computers & 0.250 & 0.136 & 0.142 & 0.110 & 0.555 & 0.239 \\
\hline Computer peripherals & 0.235 & 0.247 & 0.324 & 0.279 & 0.372 & 0.291 \\
\hline Office equipment & 0.152 & 0.310 & 0.293 & 0.307 & 0.180 & 0.248 \\
\hline $\begin{array}{l}\text { Medical equipment and } \\
\text { appliances }\end{array}$ & 0.314 & 0.357 & 0.685 & 0.619 & 0.227 & 0.440 \\
\hline Measuring instruments & 0.698 & 0.721 & 0.894 & 0.852 & 0.456 & 0.724 \\
\hline Mean & 0.489 & 0.472 & 0.573 & 0.509 & 0.367 & 0.482 \\
\hline
\end{tabular}

Source: Authors' own estimation.

It can be seen from Table 13.3 that, when using the number of new product development projects as the indicator of innovation output, the electronic components industry, measuring instruments industry and chemical medicines industry were significantly better than others in innovation efficiency. This could be closely associated with their greater experience in global 
competition and deeper integration into the global value chain than other industries. The innovation efficiency of the manufacture of spacecraft was the lowest - only 0.181, which is greatly below that of the electronic components industry (0.761). The innovation efficiency of the computer industry was also relatively low. These two industries are related with a state's security. Obviously, there is still a long way to go to improve the innovation capability of high-tech industry.

From the perspective of the dynamic trends, the innovation efficiency of China's high-tech industry remained low during 2006-10. It reached its peak in 2008 and then declined dramatically. Such a dividing line indicates that the international financial crisis changed the dynamics in many industries. Overall, the innovation efficiency of China's high-tech industry increased slowly in the past five years, leaving much room for further improvement.

Table 13.4 Estimated Innovative Efficiency (with the sales revenue of new products as the indicator of innovation output)

\begin{tabular}{|l|l|l|l|l|l|}
\hline Industry & $\mathbf{2 0 0 7}$ & $\mathbf{2 0 0 8}$ & $\mathbf{2 0 0 9}$ & $\mathbf{2 0 1 0}$ & Mean \\
\hline Chemical medicines & 0.591 & 0.695 & 0.743 & 0.730 & 0.690 \\
\hline Finished traditional Chinese medicines & 0.387 & 0.444 & 0.507 & 0.563 & 0.475 \\
\hline Biological and biochemical products & 0.381 & 0.627 & 0.573 & 0.312 & 0.473 \\
\hline Aeroplane making and repair & 0.776 & 0.762 & 0.369 & 0.404 & 0.578 \\
\hline Spacecraft & 0.038 & 0.104 & 0.067 & 0.064 & 0.068 \\
\hline Communications equipment & 0.833 & 0.825 & 0.878 & 0.846 & 0.846 \\
\hline Radar and its fittings & 0.551 & 0.231 & 0.149 & 0.375 & 0.326 \\
\hline Broadcasting and television equipment & 0.531 & 0.400 & 0.481 & 0.305 & 0.429 \\
\hline Electronic appliances & 0.721 & 0.767 & 0.800 & 0.729 & 0.754 \\
\hline Electronic components & 0.726 & 0.619 & 0.738 & 0.770 & 0.713 \\
\hline Domestic televisions and radios & 0.694 & 0.710 & 0.777 & 0.733 & 0.729 \\
\hline Other electronic equipment & 0.590 & 0.869 & 0.781 & 0.520 & 0.690 \\
\hline Computers & 0.905 & 0.884 & 0.809 & 0.874 & 0.868 \\
\hline Computer peripherals & 0.865 & 0.866 & 0.670 & 0.894 & 0.824 \\
\hline Office equipment & 0.804 & 0.480 & 0.385 & 0.681 & 0.587 \\
\hline Medical equipment and appliances & 0.264 & 0.444 & 0.445 & 0.174 & 0.332 \\
\hline Measuring instruments & 0.691 & 0.828 & 0.801 & 0.613 & 0.733 \\
\hline Mean & 0.609 & 0.621 & 0.587 & 0.564 & 0.595 \\
\hline & & & & &
\end{tabular}

Source: Authors' own estimation.

It can be seen from Table 13.4 that, when using the sales revenue of new products as the indicator of innovation output, computers, communications equipment and computer peripherals were significantly better than other 
industries in innovation efficiency. This could be a result of the huge consumer market for these industries in China. The average innovation efficiency of the manufacture of spacecraft industry was the lowest - only 0.068 - significantly lower than that of the computer industry, with the highest innovation efficiency (0.868). It is clear that there are enormous obstacles for the commercialisation of the $R \& D$ results in China's spacecraft industry.

Though different indicators are used to measure innovation output, we can see the trend of the changes in the innovation efficiency of China's high-tech industry is consistent - that is, an inverted U-shape.

\section{Conclusions}

A country's international competitiveness and its role in the world economy depend on its innovation capability in high-tech industry, which is also an important indicator for developing countries to graduate to developed status. In this chapter, the stochastic frontier knowledge production function model is applied to conduct an empirical analysis of innovation efficiency of China's hightech industry in transition. The results show that, during the period 2005-10

1. the knowledge stock did not play a major role in China's high-tech industry innovation

2. the effects of acquisition of foreign technology on innovation capability in China's high-tech industry were not statistically obvious

3. the effects of the purchase of domestic technology on the R\&D output of China's high-tech industry were obvious, but the economic benefits due to the purchase of domestic technology were not statistically obvious

4. the scale of enterprises in China's high-tech industry had a negative impact on their innovation capability.

The above conclusions have important implications for the development of China's high-tech industry.

First, due to the technological 'blockade' imposed by developed countries, the role of acquisition of foreign technologies in promoting China's hightech industry is far weaker than that in China's non-high-tech manufacturing industries. With the continuous increase of the share of China's economy in the world economy, we can expect an even stricter technological 'blockade' from the developed countries. Therefore, the main way to enhance the innovation capability of China's high-tech industry is via local innovation, with the importation of foreign technologies as a complementary trend. More preferential policies and public funds should be invested in the high-tech industries, 
especially in the enterprises that have already exhibited innovative ability in strategic high-tech industry. Through this channel, China's high-tech industry can enhance its innovation capacity and international competitiveness more quickly and occupy the high end of the global industry chain.

Second, as to the poor quality of China's high-tech industrial development, China should change the practice that evaluates regional economic restructuring mainly by the output of high-tech industry, and construct a scientific evaluation system to guide local governments to pay more attention to the quality of the high-tech industry's development. It will greatly reduce the phenomenon in which high-tech industry is treated as the Government's 'achievement projects' when promoting economic transformation. At present, many technological breakthroughs in China cannot be commercialised and receive returns from the market, which greatly reduces the enthusiasm of enterprises for technological innovation. Thus, it is necessary for the Government to regulate monopolies to create a favourable environment for innovation and enable the innovator to realise market value more easily. China must make great efforts to establish various types of intermediaries and create a complete business model that can commercialise the major technologies. Only in this way can China fundamentally address the problems of poor-quality industrial development in its high-tech industry.

Third, the empirical result that the effects of purchasing domestic technology on the R\&D output of China's high-tech industry was obvious, but the economic benefits due to the purchase of domestic technology were not statistically obvious shows that technology transfer and cooperation between China's enterprises does help to promote the R\&D activities of high-tech industry. Without technological barriers, enterprises can make their cooperative R\&D on key technologies more efficient through the technology transfer between them. It also confirms the effectiveness of industrial technology innovation alliances among enterprises. It is a good way to accelerate the integration of enterprises' technologies and overcome the key and common technological challenges constraining the development of the industry under the guidance of the Government. But, on the other hand, the lack of obvious measurable economic benefits reveals that there is room for further improvement in the back-end operations of the technology innovation alliance among enterprises. In addition to improving the business model, it is also very important to coordinate different types of enterprises to take on appropriate responsibilities and work together to develop technological applications with greater commercial value after achieving breakthroughs in key and common technologies. This will ensure that the enterprises in the same alliance can position themselves correctly in cooperative R\&D according to the location of their products in the industrial chain, and carry out strategic arrangements to occupy the corresponding market. In this process, the market 
mechanism is the principal determinant, while the Government plays only a guiding role. Intermediary organisations such as industrial associations and professional investors could exert a greater influence; this is the third force to promote innovation that China needs to cultivate and develop in the future.

Fourth, according to the empirical result that the size of enterprises in China's high-tech industry had a negative impact on their innovation capability, we would make two points. On one hand, it shows once again that being stateowned is an institutional barrier that has been an important factor hindering the functioning of enterprises' innovation capability, as most of the large high-tech enterprises in China are state-owned. It has been a prominent issue during China's current economic restructuring and institutional reform that the state-owned enterprises have insufficient motives for innovation. How can an effective incentive mechanism be established to stimulate the innovation of state-owned enterprises? It is a problem highlighted in the current pattern of reform and changing economic development that requires great attention from relevant departments and is critical to the success of transition to some extent. On the other hand, the empirical result further argues for the important role of small and medium-sized high-tech enterprises in the process of economic restructuring and changing development mode. It is a crucial issue for the successful transformation of China's economic development mode in the future: how to enhance the innovative enthusiasm and capability of small and mediumsized high-tech enterprises? For the large number of small and mediumsized enterprises (SMEs) in China, due to their small size, the transformation is relatively easy for them and the opportunity cost of transformation is also relatively low. This reinforces the point that it is appropriate to set as key policy priorities the solution of SMEs' financing difficulties and improving SMEs' innovation capacity. This policy should absolutely be maintained.

Fifth, through the above analysis, in our opinion, over a long period, China should insist on its development strategy of innovation and building an innovation-oriented nation, further increase R\&D investments in enterprises, boost their innovation capability to occupy the high-end of the global value chain in the favourable period of global industrial adjustment, and drive the economic restructuring and change of economic development mode through improvement of high-tech industry's innovation capability. Meanwhile, China should further promote the cooperation of industry, colleges and institutes through policy guidance to catalyse the commercialisation of new technologies and to promote their ability to realise the market value of new technologies. China should also carry out various initiatives to speed up technology incubation, create new business models to enhance the value added of high-tech industry's products, combine technological innovation, financial innovation, industrial innovation and business model innovation to form a strong power 
to improve the overall innovation capability of China's high-tech industry, provide support and play a leading role in accelerating China's transformation of economic development modes.

Finally, it should be noted that there are still shortcomings in this study. For example, when determining the factors affecting innovation efficiency, due to the availability of data, only the expenditure for acquisition of foreign technology and purchase of domestic technology and enterprise size are taken into consideration, with industrial market structure, profitability and other factors being ignored. In this sense, the conclusions in this chapter are limited. These issues should be overcome and improved in our future research.

\section{References}

Acs, Z. J., FitzRoy, F. R. and Smith, I., 2002, 'High-technology employment and R\&D in cities: heterogeneity vs specialization', The Annals of Regional Science, vol. 36, no. 3, pp. 373-86.

Aigner, D., Lovell, C. A. K. and Schmidt, P., 1977, 'Formulation and estimation of stochastic frontier production function models', Journal of Econometrics, vol. 6 , no. 1, pp. 21-37.

Anselin, L., Varga, A. and Acs, Z. J., 1997, 'Local geographic spillovers between university research and high technology innovations', Journal of Urban Economics, vol. 42, pp. 422-48.

Battese, G. E. and Coelli, T., 1995, 'A model of technical inefficiency effects in stochastic frontier production for panel data', Empirical Economics, vol. 20, pp. 325-32.

Battese, G. E. and Corra, G. S., 1977, 'Estimation of a production frontier model: with application to the pastoral zone of eastern Australia', Australian Journal of Agricultural Economics, vol. 21, no. 3, pp. 169-79.

Blind, K. and Grupp, H., 1999, 'Interdependencies between the science and technology infrastructure and innovation activities in German regions: empirical findings and policy consequences', Research Policy, vol. 28, no. 5, pp. $451-68$.

Bode, E., 2004, 'The spatial pattern of localized R\&D spillovers: an empirical investigation for Germany', Journal of Economic Geography, vol. 4, pp. 43-64.

Comanor, W. S. and Scherer, F. M., 1969, 'Patent statistics as a measure of technical change', Journal of Political Economy, vol. 77, pp. 392-8. 
Gil, Y., Bong, S. and Lee, J., 2003, 'Integration model of technology internalization modes and learning strategy: globally late starter Samsung's successful practices in South Korea', Technovation, vol. 23, pp. 333-47.

Griliches, Z., 1979, 'Issues in assessing the contribution of research and development to productivity growth', Bell Journal of Economics, vol. 10, pp. 92-116.

Guo, G. F., Wen, J. W. and Sun, B. Y., 2007, 'The affected factor analysis of the ability of technology innovation for the six provinces of central China', Journal of Quantitative \& Technical Economics, vol. 9, pp. 134-43.

Han, J., 2010, 'An empirical analysis on China's high-tech industry innovation efficiency based on SFA', Studies in Science of Science, vol. 3, pp. 467-72.

Jaffe, A. B., 1989, 'Real effects of academic research', American Economic Review, vol. 79, no. 5, pp. 957-70.

Kumbhakar, S. C. and Lovell, C., 2000, Stochastic Frontier Analysis, Cambridge University Press, Cambridge.

Li, X. B., 2007, 'An empirical study on the transition of China's regional innovation capacity: based on the view of innovation system', Management World, vol. 12, pp. 18-30.

Meeusen, W. and van den Broeck, J., 1977, 'Efficiency estimation from CobbDouglas production functions with composed error', International Economic Review, vol. 18, pp. 435-44.

National Bureau of Statistics of China (NBS), 2009, China Statistical Yearbook on Science and Technology, 2009, China Statistics Press, Beijing.

Shi, X. S. and Zhao, S. D., 2009, 'Analysis of regional innovation efficiency and spatial discrepancy in China', Journal of Quantitative \& Technical Economics, vol. 3, pp. 45-55.

Yang, Y., 2008, 'Synthetic evaluation on self-innovation ability of enterprises: an empirical research from the perspective of the input-output efficiency', The Study of Finance and Economics, vol. 6, pp. 30-40.

Zhang, G. Q. and Feng T., 2007, 'An empirical study on the market structure, $\mathrm{R} \& \mathrm{D}$ investment and economic performance: evidence from China's hightech industry', Science and Technology Management Research, vol. 12, pp. 42-7.

Zhi, Y., 2009, 'Innovation ability, technology transformation and innovation performance: an empirical analysis of China's electronic industry's listed companies', Science of Science and Management of S. \& T., vol. 3, pp. 96-9, 131. 